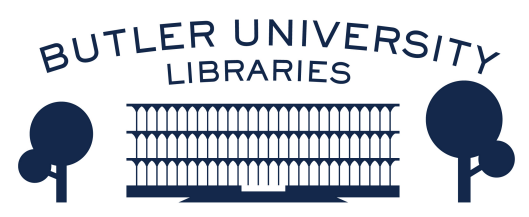

Journal of Hindu-Christian Studies

Volume 8

Article 9

January 1995

\title{
Book Review: "Mother of the Universe: Visions of the Goddess and Tantric Hymns of Enlightenment"
}

Arti Dand

Follow this and additional works at: https://digitalcommons.butler.edu/jhcs

Part of the Religion Commons

\section{Recommended Citation}

Dand, Arti (1995) "Book Review: "Mother of the Universe: Visions of the Goddess and Tantric Hymns of Enlightenment"," Journal of Hindu-Christian Studies: Vol. 8, Article 9.

Available at: https://doi.org/10.7825/2164-6279.1114

The Journal of Hindu-Christian Studies is a publication of the Society for Hindu-Christian Studies. The digital version is made available by Digital Commons @ Butler University. For questions about the Journal or the Society, please contact cbauman@butler.edu. For more information about Digital Commons @ Butler University, please contact digitalscholarship@butler.edu. 
the context of enculteration in India. The attempt is praiseworthy, where the need for a prophetic critique is admitted. But the change of metaphors cannot happen in a vacuum. First of all the socio-cultural factors that condition the thinking pattern of a believing community are to be examined to see whether such a change of metaphors is feasible. That is not done, since the scope of the book is limited to convergence and divergence in the vocabulary and images designating God in both the traditions. Secondly, one has to go into the theological implications of these metaphors before introducing feminine images of God into the Christian tradition patterned on the Hindu model. That is not done either.

But the book serves as a good source for further research. The poet Bharati's works are very well analysed and documented probably for the first time from this perspective. It is interesting to mention that Bharati himself, a Hindu poet, composed a poem on Jesus Christ, which is quite significant while comparing Christian and Hindu images of God as feminine. The poem concludes thus:

Magdalene is the Eternal Feminine, Jesus Christ is unending dharma,

Draw we close to the symbol; look, an inner meaning glows.

(Cf. Prema Nandakumar's article in this volume.)

Anand Amaladass

Madras

\section{Mother of the Universe: Visions of the Goddess and Tantric Hymns of Enlightenment. Lex Hixon. London: Quest Books, 1994, xiv +223 pp.}

\section{LEX HIXON'S BOOK Mother of the} Universe can loosely be called a "reworking" of the reflections and songs of the eighteenth-century Bengali Mystic Ramprasad Sen. Ramprasad was a poet and saint, famous in Bengal for his devotion to the great goddess of Hinduism. Hixon's poems are not based on the original Bengali of the poet, but rather on a translation of them, rendered into English by Judanath Sinha. Hixon has then revised and expanded them, with the aim of explicating Ramprasad's verse, with reference to his own experiences. In this sense, Hixon says, "rather than ... scholarly footnotes, the expanded poems themselves contain commentary on the esoteric Mother Wisdom of India" (p.xii). The resulting "contemplative visions" then are designed especially for the English reader who may appreciate Hixon's "Western sensibility about language and meaning" (p.xi) (whatever that may mean).

Mother of the Universe can best be situated in the larger schema of Goddess literature if one reads the preface to the book carefully. There Hixon confides that he was attracted to the Hindu Goddess tradition by what he feels is the natural power of the feminine metaphor, and received a formal initiation at the hands of Swami Nikhilananda, a prominent disciple of Ramakrishna and Sarada Devi. He perceives himself as a committed devotee of Mother Kali, who can now "approach and envision the Great Goddess naturally, as if I had been raised since childhood in the Divine Mother tradition of Bengal" (p.xi). His book, as a result, is clearly a religious exercise, infused with devotional purpose, and his hopes for it are quite ambitious. He says, "This book can serve as a non-doctrinal, non-official scripture of the Goddess" (p.xi), and his 
recommendation is that the poems, as "scriptural manifestation", be read each day, one at a time, and assimilated into one's daily life.

Hixon's work is a personal meditation on the divine Mother, which bases itself on the skeletal work of Ramprasad Sen. This in itself is not objectionable. All beings are entitled to such meditations, and seen from this perspective, the poems are quite sensitively reworked. As a scholarly enterprise, however, the book is highly inadequate. It is riddled with generalizations and absolutist statements, too many to even mention. There is an utter lack of selfconsciousness about scholarly method. For example, even though Hixon assures us that the poems' "startling imagery and naked honesty belong to Ramprasad. My expansions have added nothing that diverges from his spirit" (p.xii), one is given no indication whatsoever as to where Ramprasad left off, and where Hixon's contemplative commentary begins. Similarly, Hixon is sometimes so indulgent to mystical language that one sometimes becomes quite lost in a quagmire of profundity. Mother of the Universe, in short, is best read as a devotional work, suited for like-minded devotees. To read it with any other aim is to be disappointed.

Arti Dand

McGill University

\section{Theo-Monistic Mysticism: A Hindu-Christian Comparison. Michael} Stoeber. New York: St Martin's Press, 1994, 135 pp.

\begin{abstract}
THEO-MONISTIC MYSTICISM is a thoughtful and challenging study which seeks a middle path between two influential interpretations of mystical experiences. The constructivist interpreters, represented here by John Hick, admit that mystical experiences are different but argue that the differences are explicable by reference to the socio-religious framework which the particular mystic brings to her experience. Stoeber is critical of this school for its inability to account for the transmission of new religious knowledge and insight through mystical experience, since the information which the mystic receives is entirely dependent on the prior conceptual framework. In addition, the constructivist thesis cannot adequately account for mystic heresy or for the similarities in mystical experiences where there are no shared socioreligious factors.

The essentialist school, represented by interpreters like Evelyn Underhill, W. T. Stace and Ninian Smart, see mystical experience as the same everywhere, but
\end{abstract}

subject to a variety of socio-religious interpretations. Stoeber is critical of the essentialist position for its disregard of vital differences between monistic experiences, which involve a loss of duality and exclude personal experience, and theistic experiences, which encounter the Real as dynamic and where "some sense of differentiating self-identity is maintained by the participants" (p.24). These important differences are illustrated by analysis of the writings of Meister Eckhart and Jan Van Ruusbroec.

The study of these two mystics leads Stoeber to propose a third experiential possibility which he calls theo-monistic mysticism. He calls it a theo-monistic experience "because although it involves an impersonal monistic realization, it issues in a perspective that also reflects an active, creative, and personal Real" (p.35). Theomonistic mysticism avoids the extremes of the constructivist and essentialist schools by positing that mystical experiences differ and that these differences cannot be explained 